\title{
Learners' Satisfaction, Learning Style Preferences and Effective Use of an OLE
}

\author{
doi:10.3991/ijet.v3i1.760 \\ T.A. Weerasinghe ${ }^{1}$, R. Ramberg ${ }^{1}$ and K.P. Hewagamage ${ }^{2}$ \\ ${ }^{1}$ DSV-Stockholm University/KTH, Kista, Sweden \\ ${ }^{2}$ University of Colombo School of Computing, Colombo 7, Sri Lanka
}

\begin{abstract}
This paper presents the results of an empirical study conducted with a set of students using an online learning environment (OLE) to follow a distance education program. The aim of the study was to find whether students could perform well in examinations using only the Learning Management System (LMS), whether they could use it in an efficient way and whether there was a relationship between students' learning styles, number of LMS hits and learning achievements. The students were given access to a specially designed course section.
\end{abstract}

The students' learning achievements were evaluated in two tests at different intervals. The study data were gathered using questionnaires and LMS statistics. We found that once the students got acquainted with the environment they could use the LMS more efficiently and managed to get high scores by only using the LMS. Results associated with the learning style preferences imply that we have designed the learning content and the environment to satisfy and support the learners with different learning style preferences.

Index Terms-Distance Education, Online Learning Environment (OLE), Learning Management System (LMS), Learning Styles

\section{INTRODUCTION}

Online learning environment (OLE)s are designed with learning content, student self evaluations, help facilities and many other features to support learning. In spite of this the literature reporting failures of e-learning practices is on a rapid increase in the 21 st century [1]. The main reason for this is that the course developers do not consider how people learn in designing their courses [2]. In online learning environment (OLE)s, creating of instructional material is considered as one of the main duties of the teacher. Garrison and Anderson [3] support this reasoning by saying; a teacher is responsible of designing and creating educational activities. Also, Sherry [4] emphasises the importance of having skill and knowledge of instructional design for teachers. But teachers may not be good instructional designers. Also, if teachers try to create interactive e-learning content by themselves it can cause a burden for the teachers at least at the beginning of the programme.

However, the idea of introducing e-learning as a method of delivering lessons to students has also proven to be beneficial to both teachers and students. According to Gentilucci [5], the teacher should be freed from the pressure of being the only source of information and instead he should be a facilitator in supporting and guiding the learner to use online learning content. Besides that, using e-learning in teaching creates opportunities for the students to do studies in a different way which makes learning more student-centred and personally interactive [6]. Therefore, it is important to get the students' feedback after introducing e-learning to any distance education programme. Students' satisfaction of the online learning programme is considered as the major driver for the success or failure of such medium [7]. The satisfaction of the OLE depends greatly on the learners' attitudes and experience gained by using the OLE. Ecom, Wen and Ashill [8] report that course structure, self-motivation, learning styles, interaction and facilitation influence students' satisfaction. Swan et al. [9] have done a study in the USA where students are quite familiar with technology enhanced learning environments and report that the greater the consistency among course modules, the more satisfied the learners were, the more they thought they learnt and had interactions with their instructors. The results of their study focus on the importance of having knowledge building communities for the successfulness of online courses. Lupo and Erlich [10] have used an OLE with some face-to-face tutoring meetings at the beginning of the course and report that their course was successful in terms of students' satisfaction and perceived learning. But in practice there are lots of students in a distance education programme and it is not possible to gather them all and conduct face-to-face learning sessions.

Different learners have different learning styles and it is important to know students' learning styles for course design and delivery [11]. Because learners' learning style preference (LSP)s can be a major factor which influences the effectiveness of any learning programme [12]. Valenta et al. [13] conclude that there is a need for future research to understand the relationship between learning styles and learning experience of online learners.

Research on these issues has of course been conducted. However, the results reported are far from clear-cut. Gururajan [14] has conducted a study to find whether there is a relationship between the learning style preferences and the effectiveness of an end-user computing (EUC) training programme. The effectiveness of the training was measured using the score gained by the learners in doing the tasks using the application software. He reports that there was no difference in effectiveness due to learning style preferences. However, Gururajan has conducted his test in a classroom setting and we cannot assume that same result can be achieved in online learning. Shaw and Marlow [15] have investigated whether there is a relationship between the students' learning style preferences and the degree to which the 
students accept the integration of information communication technology (ICT) into a curriculum. They report that their theorists had more negative attitudes towards ICT. Downing and Chim [16] have done a study with a set of first year students at the City University of Hong Kong and noted "Reflectors at least are online Extraverts"(273p). These different conclusions made by different researchers motivated us further to find whether there is a relationship between students' satisfaction, learning achievements and learning styles in an OLE.

The effectiveness of the OLE for the learners implies how helpful the learning environment is for the students to achieve the learning objectives. Therefore, in this study the effectiveness of the OLE is measured with students' learning achievements. Liaw, Huang and Chen [17] consider 'instructor-led learning environment' as one of the main characteristics of an efficient e-learning environment. However, the study of Sabry and Baldwin [18] demonstrated that learner's interaction with the learning content was more useful than other interactions that took place in a web-based learning environment. Therefore, our effort was to find out whether students could successfully learn only using an OLE where they would find less instructor support but more learnercontent interactions. The study was conducted in a country where students have less computer facilities and poor network bandwidth [19].

\section{A. Online Learning Environment(OLE) for BIT Undergraduates}

University of Colombo School of Computing (UCSC) in Sri Lanka provides interactive online learning content to the Bachelor of Information Technology (BIT) degree program (http://www.bit.lk) through its Learning Management System (LMS) at http://lms.bit.lk. BIT is an external degree programme where students do not get any lectures from their respective course teachers of the BIT programme. But there are private institutes who conduct courses based on the BIT curriculum. UCSC is having a separate team with instructional designer (ID)s to design and develop e-learning content [20]. The teachers are supposed to provide their teaching materials or notes to the IDs and support them by checking the product at different intervals to verify the subject matter.

Learning through an LMS is quite new to the 1st Semester students of BIT who come from Sri Lankan schools where the main method of training is face-to-face teaching. Therefore, UCSC needs to create an OLE where learners will find what they really need to do their studies well and consequently increase pass rates of the BIT degree programme.

\section{B. Factors Affecting e-Learning}

As Stolovitch and Keeps [21] describe, there are three major factors; ability to learn, prior knowledge and motivation that influence how much and how well humans learn. In an OLE the learners can study on their own time tables and they can select activities or lessons as they want. Therefore, when the system is providing them learning content with appropriate instructional design methodology [22] the adult learners can get the maximum benefit of learning independent of their learning ability. But for that, learners with less learning abilities should be highly motivated and hard working. Motivation for learning is affected by three major factors; value, confidence and mood [21]. Therefore, it is important to know whether students value the OLE, how confident they are to use the LMS and whether the students have positive expectations putting them in a good mood for learning.

There are some negative factors which hinder students scoring high marks at the examinations even if they study diligently. Personal factors like work load of the job and distressed home environment are some of the main negative influences of e-learners [23]. There are many other negative factors which ultimately trouble learners' mind and badly influence their learning.

Different learners have different learning styles which are students' preferred methods or modes of learning [24]. Understanding of learning style preferences of students help to design courses to facilitate learning of individual students [25]. There are different types of learning style instruments to find the learning styles of students. The Learning Style Questionnaire (LSQ) is one such learning style instrument which is developed by Peter Honey and Alan Mumford based on Kolb's learning style theory [26]. According to Allinson's and Hayes's [27] comment, the LSQ is a relatively more reliable instrument than Kolb's Learning Style Inventory. The LSQ has been used and tested by many researchers and commented as a valid and reliable learning style questionnaire (e.g. [28], [27], [29]). Honey [30] has reported that a 40-items version of the LSQ is designed for young learners who are not in managerial roles. The majority of the BIT students who participated in this study belong to the age group of 20-25 years. Therefore, in the present study we used Honey's and Mumford's 40-item LSQ to identify the students' learning style preferences.

The LSQ describes learners with respect to four learning styles; Activist, Theorist, Reflector and Pragmatist. According to the explanation given on the LSQ [30];

Activists like to learn by doing. They like to take challenges and experience new things. They want to try out exercises or participate in activities without thinking of the consequences.

Reflectors learn by observing and thinking about what happened. They listen carefully to everyone, think over all ideas and repeat the learning when they get a chance to do it.

Theorists like to see concepts, models and the overall image of the lesson. The content needs to be presented in an order and explained from the simple things to details.

Pragmatists learn best when they are given a chance to practice what is immediately demonstrated or explained. They enjoy experimenting with new ideas.

\section{Aim of the Study}

After introducing the LMS to the BIT students, UCSC observed an improvement in pass rates and an increment in the number of self-study students [31]. The increase in pass rates and number of self-study students could be taken as a sign of the students being satisfied with the elearning environment, but we do not know to what extent and more specifically regarding what particular features of the environment they are satisfied with. This motivated us to more closely investigate whether;

1. students are satisfied with the OLE, 
2. students can perform well in examinations if they use only the LMS for their studies,

3. students can use the OLE in an efficient way and

4. whether there is a relationship between students' learning styles, online learning content access records and their learning achievements.

\section{MethoDS}

\section{A. Participants}

The study was done with a sample of students who sat the 1st semester exam of the BIT degree programme at the UCSC in March 2008. The 1st semester started in October 2007 and the LMS was available for them from the last week of October 2007. There were 2526 students who got registered to the 1 st semester.

In December 2007, 120 students of BIT semester 1 were selected to do this study by considering the number of hits done by each student and their residential province. All the students were novice e-learners and none of them had experience in using a Learning Management System (LMS) for learning before joining with the BIT degree program. The students participated in this study while following the other courses in the semester. The selected students were not isolated or grouped in the LMS.

The study included three face-to-face meetings with the students. Only 40 students participated in the 1st meeting to start the study. However, only 27 students participated in all 3 meetings and the group was formed of 18 males and 9 females. The majority of the students belong to the age group of 20-25.

\section{B. Material}

Online Learning Content: The selected course section for this study deals with a rather practical subject. It introduces web design techniques to the students and provides necessary skills to design and develop web sites using the Dreamweaver application software. The interactive learning contents of the course section were designed and developed by the 1 st author of this paper and uploaded to the LMS. The learning contents were designed considering 'how people learn' and 'the nature of the knowledge' [32]. For example different presentation methods were used in designing instructional messages with concepts and facts. Text was used to introduce the key words in the lesson. Activities were added to practice and evaluate students' knowledge or skills by themselves. Activity pages were designed based on the lesson content on each page and attached to the relevant lesson content pages (Figure 1).

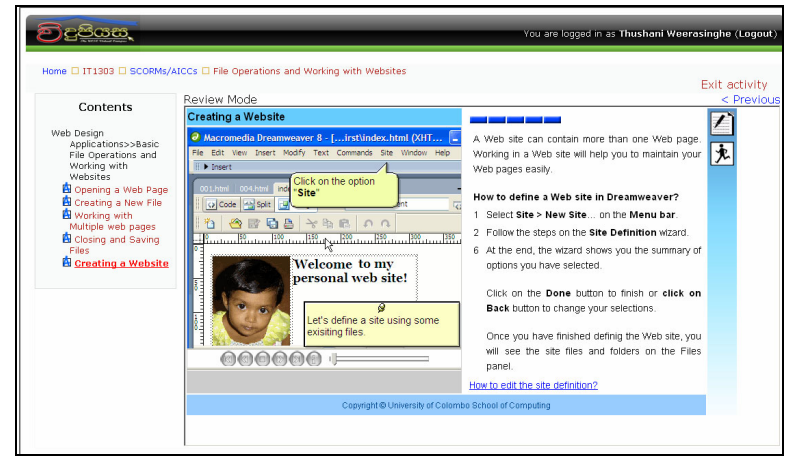

Figure 1. A lesson page

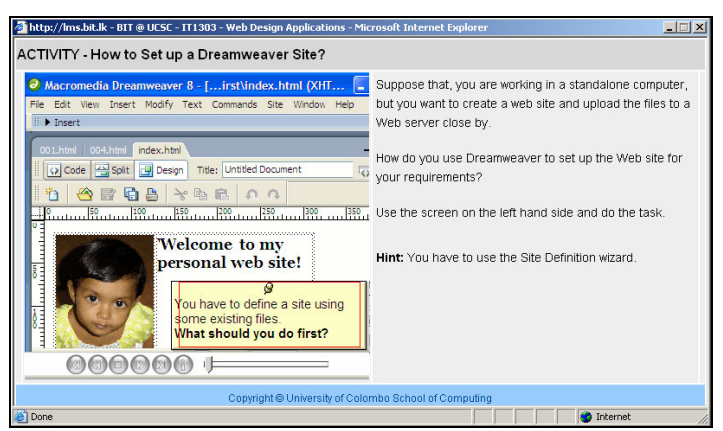

Figure 2. The activity page pop ups from the lesson page in Fig. 1

We applied the scaffolding method [33] to teach the most difficult parts of the lesson. For example, the simulations given on the lesson page as demonstrations or activities with guided text were later given as activities without guided text (Figure 2).

Most of the activities led to forum discussions (Figure 3) creating collaborative learning environments. The students could upload their answers of the exercises and discuss with the facilitators and the other students via forums, a chat room and the private message facility in the LMS.

A Practice Quiz was provided on the LMS for the learners to practice answering to a set of multiple choice questions based on the content of the course section.

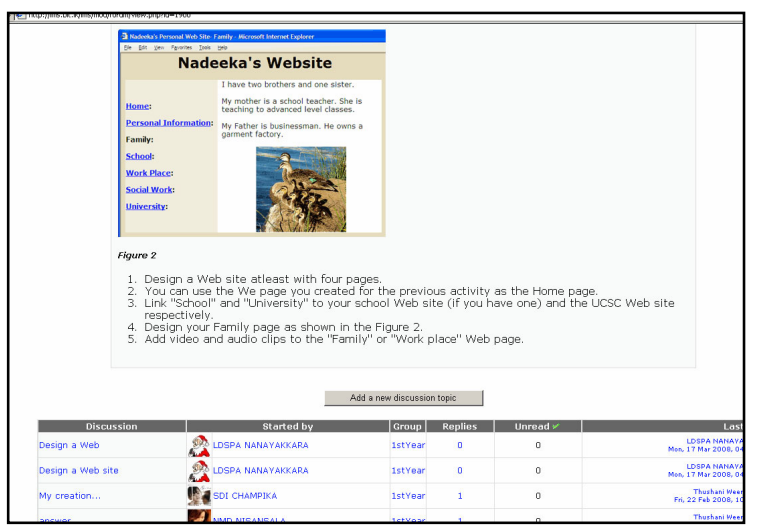

Figure 3. A forum to discuss a learning activity

Students' Learning Achievements: We used two test papers; Test 1 and Test 2 to evaluate students' learning achievements. The duration of each test paper was 30 minutes and each consisted of a set of multiple choice questions. The questions in Test 1 covered the first three sub-sections and Test 2 covered the rest of the subsections of the target course section appearing on the LMS.

Questionnaires: Two different types of questionnaires were used in this study.

1. LSQ: Learning Style Questionnaire obtained from Honey and Mumford publications- Students rated a set of 40 statements. Each statement asked whether the student agreed or disagreed with it.

2. LEQ (Learning Evaluation Questionnaire): A questionnaire based on the Tests and the studies on the LMS - The LEQ consisted of questions on a Likert Scale, dichotomous questions, filter or contingency questions and unstructured or openended questions which made the students to write 
any comments freely. The questions concerned students' general attitudes regarding online learning, specific attitudes about the OLE in the LMS and how helpful the LMS was for the student to answer the test.

\section{Design of the Study}

We did our study in the middle of the semester. It was the best time to do this study because by that time the students had had enough time to get familiar with the LMS and none of the private institutes had started teaching the course section we selected. Conducting the study at that time helped us to make students' participating in the OLE mandatory for their learning. This line of reasoning is supported by Beyth-Marom et al. [34] saying that the successfulness of OLE cannot be judged as long as students' participating in it is optional. Because students' learning achievements are measured at examinations, if participating in OLE is optional for students' learning then they can learn from face-to-face environments and eventually it will not be possible to determine the learning actually gained from the OLE.

We grouped the active students who used LMS at least once a week by their places of residence. We could select a random sample of 250 students including all provinces and invite for a meeting. Only 120 students confirmed their participation. Even though it was a small group with respect to the total number of registered students, it represented students from all major provinces of the country.

The study was done in three meetings (Figure 4). There was no comparison group for this study. As one of our aims was to find out whether students can study efficiently only using the LMS, we attempted to control the variables of students' getting any face-to-face teaching during the study period and whether they had prior knowledge of the subject matter.

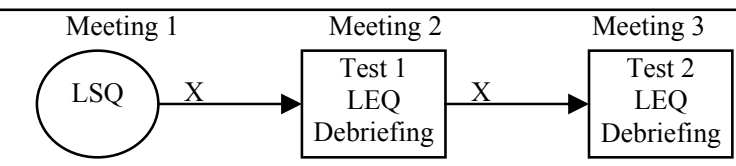

$\mathrm{X}_{1}$ : Lesson Sub-Section1 $\mathrm{X}_{2}$ : Lesson Sub-Section2

Figure 4. Study Design

\section{Procedure}

The study was done in three weeks with three face-toface meetings. At the first meeting, the LSQ was distributed. The meaning of each statement in the questionnaire was simplified to make the students clearly understand before answering the questionnaire. Students answered the questionnaire independently. The purpose of the meeting and the plans for the future meetings were explained and the students expressed their willingness and possibilities to participate in future meetings.

Interactive learning contents for sub-sections of the lesson were uploaded to the LMS at a weekly basis. Forums to discuss the subject matter were made available with the interactive learning content. Students were informed of the course updates through e-mails.

There were two tests; Test 1 and Test 2. Test 1 was conducted at the $2^{\text {nd }}$ meeting and Test 2 was conducted at the $3^{\text {rd }}$ meeting. The students were given 1 week of study period before each test. The students who expressed their willingness to participate in the future meetings were invited for the meetings. Students filled in the LEQ and participated in the debriefings on each day after the test.

\section{RESULTS}

\section{A. Results of the LEQ and the Debriefings:}

The questions raised in the LEQ were categorized into focal areas of the study. Students' answers for the questions on the Likert Scale were represented with 10,5, $0,-5$ and-10 in the order of most positive to most negative attitudes or experiences. The averages and the standard deviation (SD)s of those results are presented in Table 1. According to that, the average values of students' attitudes at meeting 3 are higher than those at meeting 2 . When moving from meeting 2 to meeting 3 the students had found more possible methods or ways of accessing the Internet and thereby they could increase the LMS access time. They could more easily discuss their problems using OLE. According to the results of the debriefings, the students had not received any formal teaching from a face to face environment and they had only discussed their problems with their institute teachers.

However, Table 1 shows that they had obtained lesser support for their studies for Test 2 than for Test 1, they could do more activities and OLE helped them more to score in Test 2 . The students had improved their reading skill and they believed that they could have scored more if they had done some more activities. The SDs of average values of students' attitudes and experiences at meeting 3 were lower than that at meeting 2 and it implies that most of the students had somewhat similar attitudes and experiences regarding the OLE.

The students had faced more learning difficulties in studying for Test 2 than Test 1 . According to the students' explanations they had faced some technical problems in accessing activities with simulations. The activities were placed on links to the learning content pages. A plausible interpretation is that during the study period before the $3^{\text {rd }}$ meeting the students were motivated to go through all the content on the OLE.

Further the results obtained from the debriefings reported that;

- the quality and the standard of the learning content used in the study was almost the same as of the other courses in the BIT LMS.

- learning content used in this study had more interactive learning content and activities.

- there were some problems in accessing heavy graphics and animations.

- the students could learn more from the online learning environment and it was better than what they normally received in some face-to-face teaching sessions.

- the students were satisfied with the learning facilities like learning content, discussion environments, private messaging facility, activities and quizzes provided in the OLE. 
TABLE I.

RESULTS OF THE LEQ OF MEETING 2 AND 3

\begin{tabular}{|c|c|c|c|c|c|}
\hline & & \multicolumn{2}{|c|}{ Meeting 2} & \multicolumn{2}{|c|}{ Meeting 3} \\
\hline & & AVG & SD & $\mathrm{AVG}$ & SD \\
\hline \multirow[b]{2}{*}{ Practical capability to do } & Have a possible Internet access point & 7.14 & 4.89 & 8.33 & 2.42 \\
\hline & Often Use OLE & 5.48 & 4.98 & 5.95 & 4.36 \\
\hline \multirow{4}{*}{$\begin{array}{l}\text { General attitudes gained by } \\
\text { experiencing the OLE }\end{array}$} & Usefulness of e-learning material & 8.10 & 3.70 & 8.10 & 2.49 \\
\hline & Confidence in using the OLE & 6.19 & 4.45 & 7.14 & 2.99 \\
\hline & OLE solves problems & 2.86 & 6.24 & 7.14 & 2.54 \\
\hline & Can learn successfully only using the OLE & -1.43 & 10.14 & 0.95 & 9.95 \\
\hline \multirow{5}{*}{$\begin{array}{l}\text { Factors affecting the score of the } \\
\text { test result }\end{array}$} & Could easily discuss my problems & 1.19 & 6.31 & 3.10 & 5.58 \\
\hline & Helpfulness of OLE to score in test & 5.00 & 4.74 & 7.62 & 3.75 \\
\hline & Did not get any support from a f2f environment & 2.38 & 9.95 & 3.57 & 7.61 \\
\hline & Did all the activities & -1.43 & 6.55 & 3.33 & 9.66 \\
\hline & Did not have prior knowledge & -7.62 & 6.05 & -7.62 & 6.05 \\
\hline \multirow{2}{*}{$\begin{array}{l}\text { Specific attitudes regarding online } \\
\text { learning content }\end{array}$} & Content was easy to understand & 10.00 & 0.00 & 10.00 & 0.00 \\
\hline & Did not need someone to explain & 5.24 & 8.73 & 6.19 & 8.05 \\
\hline \multirow[b]{3}{*}{ Problems } & Any learning difficulties & 0.48 & 10.24 & -1.43 & 10.14 \\
\hline & Speed of reading skill & 2.86 & 4.63 & 4.76 & 3.70 \\
\hline & Had to do more activities & 6.19 & 8.05 & 8.57 & 4.78 \\
\hline
\end{tabular}

B. Relationship between the Number of LMS Hits and the Test Scores:

TABLE II. TABLE 2: LMS ACCESSES DURING THE WEEK BEFORE THE 2ND MEETING AND TEST 1 SCORES

\begin{tabular}{|c|c|c|c|c|c|c|c|}
\hline 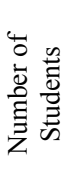 & 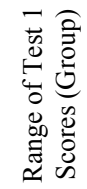 & 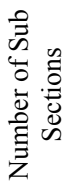 & 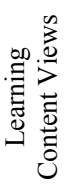 & 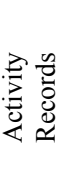 & 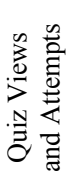 & 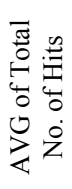 & 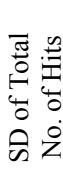 \\
\hline 2 & $50-45$ & 3 & 38 & 37 & 7 & 81 & 54 \\
\hline 2 & $44-40$ & 3 & 81 & 13 & 11 & 104 & 13 \\
\hline 6 & $39-35$ & 3 & 52 & 18 & 14 & 84 & 62 \\
\hline 7 & $34-30$ & 3 & 48 & 35 & 8 & 91 & 71 \\
\hline 3 & $29-25$ & 3 & 47 & 30 & 3 & 80 & 30 \\
\hline 1 & 24-20 & 1 & 16 & 3 & 9 & 28 & 0 \\
\hline 0 & $19-0$ & 0 & 0 & 0 & 0 & 0 & 0 \\
\hline
\end{tabular}

TABLE III. TABLE 3: LMS ACCESSES DURING THE WEEK BEFORE THE 3RD MEETING AND TEST 2 SCORES

\begin{tabular}{|c|c|c|c|c|c|c|c|}
\hline 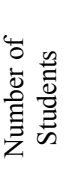 & 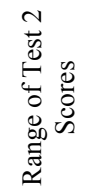 & 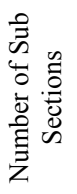 & 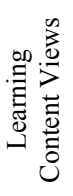 & 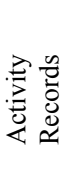 & 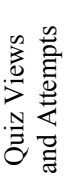 & $\begin{array}{l}\bar{\pi} \\
0 \\
0\end{array}$ & 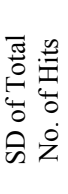 \\
\hline 0 & $50-45$ & 0 & 0 & 0 & 0 & 0 & 0 \\
\hline 4 & $44-40$ & 2 & 39 & 43 & 16 & 156 & 73 \\
\hline 5 & $39-35$ & 2 & 57 & 45 & 8 & 163 & 49 \\
\hline 8 & $34-30$ & 2 & 44 & 14 & 9 & 91 & 46 \\
\hline 3 & $29-25$ & 2 & 63 & 8 & 5 & 89 & 20 \\
\hline 1 & $24-20$ & 3 & 42 & 0 & 0 & 42 & 0 \\
\hline 0 & $19-0$ & 0 & 0 & 0 & 0 & 0 & 0 \\
\hline
\end{tabular}

The tests scores in Table 2 and 3 are on normal distributions and they imply that we have designed the two tests with equal level of difficulty. Comparatively, SD values of total number of LMS hits of Test 1 are higher than that of Test 2. Also, there is no relationship between
Test 1 scores and number of LMS hits in Table 2 . However, the results of the Test 2 show an increase in the test score with the average number of LMS hits. The students in the group 44-40 have done 156, an average of number of LMS hits which does not follow the same relationship as the other groups. But the SD of it shows that there is a considerable variance between the numbers of LMS hits of the individual students. From individual students' statistics we found that there was only one student who had not used the LMS as others but had managed to score well. Further investigating his records obtained from LEQ, we found that he had a good prior knowledge regarding the subject matter.

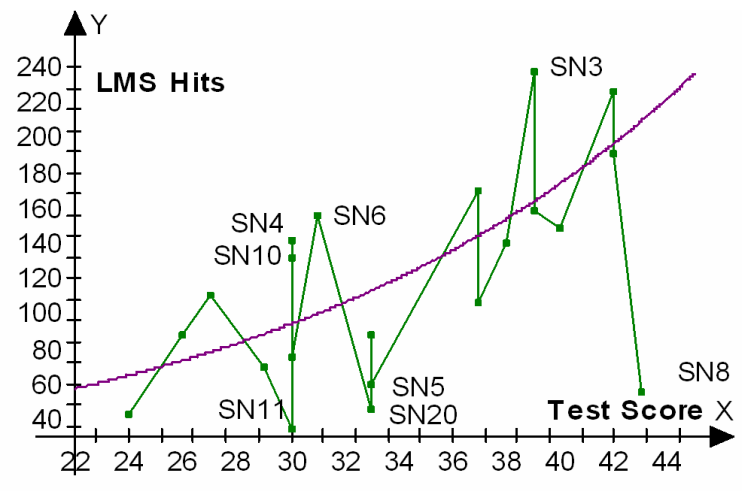

Figure 5. Test 2 scores and the LMS hits during the week before the 3rd meeting

To identify the relationship between the number of LMS hits and Test 2 results clearly, we prepared the best fit exponential curve (Exponential Regression Curve) which is presented in Figure 5. The results imply that there is a positive relationship between the test scores and the number of LMS hits. Records of all the students except 8 fall close to the regression curve. Out of them, Student Number (SN) 3, 4, 6 and 10 should have scored 
more with respect to the number of hits they have made in the LMS. SN 5, 8, 11 and 20 should have scored less.

Individual students' records obtained via LEQ report that even though SN 3, 4, 6, and 10 accessed the LMS content more than others they had faced some problems during the study period or they had not done activities or attempted quiz as others. SN 5, 8, 11 and 20 had not accessed the LMS as others but had scored relatively high. As reported on the LEQs, many of them had received support from a face-to-face environment to discuss their problems related to the subject matter or they had done activities and quiz more than others. This explanation is strengthened by the statistics shown in Table 3; that the number of quiz attempts and activity records had greatly contributed to high test scores.

Even though it was not one of our aims to find relationships between gender differences and students' learning achievements in an OLE, the results of our study significantly show that female students in our sample had used the LMS more but relatively scored low in the tests and male students had used the LMS less but relatively scored high in the tests.

\section{Learning Style Preferences:}

The results of the LSQ reports, that there were 11 Activists, 7 Reflectors, 4 Pragmatists and 6 Theorists in our sample. Among them there were 4 students with Reflector and Theorist both LSPs. 1 with Reflector and Pragmatist both LSPs. 1 with Reflector, Theorist and Pragmatist LSPs. 6 students showed more than one LSP but none had all four LSPs.

There was no significant relationship between LSPs, LMS hits and test scores. However, by analysing individual LSPs, we found that learners with different types of LSPs were there among the students who had scored 30 or more and among the students who had done more than 70 hits in the LMS.

By analysing LSPs with LEQ results (Table 4), we found that Activists and Pragmatists had felt that the learning material had been more useful, OLE had more easily solved their problems and OLE had been more helpful to score at the test. Reflectors and Theorist had experienced some technical problems in accessing the learning content and they had reported that they had lower speeds of reading. Also, Theorists had found some difficulty in discussing their problems in the OLE. Nevertheless, Theorist and Reflectors had believed more than the other two learning styles that they could learn successfully only using the OLE. Also, as a whole, students having different learning styles had positive attitudes towards the OLE and the learning content we created.

TABLE IV.

LEARNING STYLE PREFERENCES AND THE STUDENTS' ATTITUDES/EXPERIENCES AT THE 3RD MEETING

\begin{tabular}{|c|c|c|c|c|c|c|c|c|}
\hline & $\begin{array}{c}\text { Usefulness } \\
\text { of e- } \\
\text { Learning } \\
\text { material }\end{array}$ & $\begin{array}{c}\text { Can Learn } \\
\text { Successfully } \\
\text { only using } \\
\text { the OLE }\end{array}$ & $\begin{array}{c}\text { Could } \\
\text { Easily } \\
\text { Discuss } \\
\text { Problems }\end{array}$ & $\begin{array}{c}\text { Helpfulness } \\
\text { of OLE to } \\
\text { Score in } \\
\text { Test }\end{array}$ & $\begin{array}{c}\text { Content } \\
\text { was Easy to } \\
\text { Understand }\end{array}$ & $\begin{array}{c}\text { Any } \\
\text { Learning } \\
\text { Difficulties }\end{array}$ & $\begin{array}{c}\text { Speed of } \\
\text { Your } \\
\text { Reading } \\
\text { Skills }\end{array}$ & $\begin{array}{c}\text { Had to Do } \\
\text { More } \\
\text { Activities }\end{array}$ \\
\hline Activist & 8.64 & 0.00 & 4.55 & 8.18 & 10.00 & 0.91 & 4.55 & 10.00 \\
\hline Reflector & 7.14 & 1.43 & 0.00 & 6.43 & 10.00 & -10.00 & 3.57 & 5.71 \\
\hline Theorist & 7.50 & 3.33 & -0.83 & 5.83 & 10.00 & -6.67 & 3.33 & 8.33 \\
\hline Pragmatist & 8.75 & 0.00 & 2.50 & 8.75 & 10.00 & 0.00 & 5.00 & 10.00 \\
\hline
\end{tabular}

\section{SUMMARY}

\section{A. Results of the LEQ and Debriefings:}

According to the results of the LEQ at the 2nd meeting, the majority of the students did not believe that they could learn only using the OLE and most of them had not completed all activities on the LMS. Conversely, the average values of the other attitudes towards the OLE and experiences were positive. However, when moving from the meeting 2 to meeting 3 , the majority of the students could successfully learn only using the OLE and they could complete all the learning activities on the OLE. But as a result, they had found more learning difficulties than before. According to the explanations on the LEQ and debriefing, the students had faced some technical problems in accessing the activities with simulations and heavy graphics. As activities were placed in the internal links on the lesson pages, a plausible interpretation is that during the study period before the $3^{\text {rd }}$ meeting the students were motivated to go through all the content on the OLE. Results of the debriefing report that the learning content used in this study was more interactive and had more activities but the standard and quality were almost the same as what they found in other courses in the LMS.

\section{B. Relationship between the Number of LMS Hits and the Test Scores:}

The test scores in Table 2 and 3 are on normal distributions. They imply that the two tests were of equal level of difficulty. But standard deviations of the LMS hits for Test 1 show that our students had not accessed the LMS a similar number of times to score equally at the test. However, the standard deviation results of Test 2 show that except one group all the other groups did not have a considerable variance of test scores within the group.

Further, the Graph drawn with Test 2 results and LMS hits showed a relationship between the test scores and the number of LMS hits. Records of all the students except 8 fell close to the regression curve. There was an improvement of the relationship between LMS hits and test scores from the results of meeting 2 to meeting 3 . This implies that in the future we may be able to predict students' learning achievements by observing their LMS access records. 


\section{Relationship between learning style preferences and other varables:}

The results of the LSQ reports, that there were 11 Activists, 7 Reflectors, 4 Pragmatists and 6 Theorists in our sample. Among them there were 4 students with Reflector and Theorist both LSPs. 1 with Reflector and Pragmatist both LSPs. 1 with Reflector, Theorist and Pragmatist LSPs. 6 students showed more than one LSP but none had all four LSPs.

By analysing the students' learning achievements and LMS statistics, we found that there were students with different types of learning styles among the group of students who scored well by accessing the LMS more. When moving from the Test 1 to Test 2 the students with different types of LSPs could improve their learning achievements and could positively improve their attitudes towards the LMS.

Results obtained by analysing LSPs with LEQ report that Activists and Pragmatists had somewhat similar experiences or attitudes towards the OLE while Reflectors and Theorists had somewhat similar experiences or attitudes towards the OLE. However, they all seemed to have positive attitudes towards the OLE and its learning content.

\section{DISCUSSION}

In the present study we quantitatively and qualitatively explored the students' attitudes and experience in using the learning content for their studies. Also, we used quantitative measures of the students' learning achievements and how much they have used the online learning environment for their studies.

The study was based on a rather practical subject; 'Using Dreamweaver to Design Web Pages' and its learning objectives were targeting at skills and factual knowledge. Turner-Bisset [35] says that the courses which target at complex amalgams of concepts, factual knowledge and skills cannot be successfully taught in elearning media. The study of Piccoli et al. [36] report that their students were not satisfied with the virtual learning environment they used and the students' satisfaction declined further during the semester. However, in the study reported in this paper we found that once the students got familiar with the OLE their attitudes towards the OLE changed from rather negative to more positive. Also, results of the LEQ reports that once students got used to the new learning environment they could find that they could easily discuss problems, they did not need support from a face-to-face environment, they were motivated to complete all activities and OLE helped them to score well in the test. These results imply that the students were quite satisfied with the OLE and its content. Hence the results of the present study on students' satisfaction with the OLE comply with the conclusions done by Lupo, Erlich [10], Motiwalla and Tello [37].

Cavanaugh [38] advices that educators who plan to implement distance education should not expect any difference in academic performance as a result. However surprisingly the results of this study reported that the students could use the OLE effectively in their studies and they could score well by only using the OLE. Also, during the study period students needed less support from the instructor or the course coordinator. This may support the conclusion made by Sabry and Baldwin [18] who reported that learner's interaction with the learning content was more useful than other interactions taken place in a webbased learning environment.

Moreover, the results of this study imply that our OLE had equally supported students with different learning style preferences and it supports the conclusion made by $\mathrm{Lu}$ et al. [39] who reported that their students could learn equally well in a WebCT-based MIS course irrespective of their different learning styles. Salmon [40] reported that Reflectors are Introverts in online learning environments. However, according to our findings Reflectors interacts with the learning material, quiz and forum based activities as others. Therefore, our results may support the argument of Downing and Chim [16] who affirmed that Reflectors at least are 'online Extraverts'. Theorists found in our study reported that they experienced more difficulties in the OLE. But it does not imply that the more 'Theorist' the learner is the more negative his attitudes in using computers for learning which is concluded by Shaw and Marlow [15] who used the same LSQ that we used but did a study with a computer assisted learning environment. Paradoxically, we found that our Theorists were having more positive attitudes towards the OLE than others by reporting that they could learn successfully using only the OLE.

The results obtained in the debriefing reported that the course section used in this study was designed in the same quality and standard of other courses in the LMS. The team of instructional designers at UCSC work according to the advice and guidance of the respective course teachers [20]. Therefore, we can assume if the $1^{\text {st }}$ author of this paper got the instructional designers to design the learning content for this study, we might have received at least somewhat close results to the results of this study. Hence, that may contradict Garrison's and Anderson's [3] reasoning and we would like to emphasize that the teacher is not the only one who is responsible in designing and developing effective and efficient e-learning content for distance learning programmes. It is important to have a team of instructional content developers for distance elearning courses and that will help to reduce the weight on the shoulders of the teachers who are willing to conduct distance e-learning courses.

\section{LiMITATIONS AND FUTURE WORK}

There were some methodological limitations to this study. Firstly the size of our sample was not enough to group students in four learning styles having a significant number in each. According to the nature of the BIT programme it was not easy to make a large number of students to participate in a series of face-to-face workshops and we had to accept the number of students willing to spend their time with us.

Secondly, there could be other variables explaining individual's learning ability, which would have helped to explain the student's behaviours of those that showed deviations from the expected behaviours. But measuring of outcomes for these types of variables is problematic in nature [41].

Thirdly, the coordinator of the course selected for this study and the main researcher was the same person and that might have influenced self-reports of the students. But on the other hand that supported us to prepare test questions with the same standard as of the final test. 
The results of this study motivated us to further investigate the instructional design methodology we used in this study to make this work successful. The online learning content and the environment can be further improved with student's suggestions and a more specific study can be conducted to find out how effective each and every component of the LMS content is.

\section{CONCLUSION}

This paper has presented the results of an empirical study conducted with an online learning environment (OLE) designed for a distance education program. The aim of the study was to find whether students were satisfied with the online learning content and its environment, whether they could efficiently learn only using the OLE and whether we had successfully designed the OLE associated with the (Learning Management System) LMS and whether there was a relationship between learning styles, LMS hits and Test scores. We found that the students' satisfaction towards the OLE increased gradually and the students could use the OLE more efficiently in their studies once they got acquainted with the OLE. The results of this study suggested that in the future we may be able to predict students' learning achievements by observing their LMS access records. The change of students' attitudes towards the learning content and the environment from slightly negative to more positive implied that we had successfully designed the learning material and the environment. Further, students' self-reports gave witness to that the quality and the standard of the content of the OLE was the same as the other courses on the OLE implying that online distance educational courses can be designed and developed without giving an extra burden to teachers. The results obtained by analysing students' learning style preferences with students' attitudes, LMS hits and test scores implied that students' with different learning style preferences were satisfied and could learn efficiently using the OLE

\section{ACKNOWLEDGEMENT}

Our special thanks would be bestowed to the staff at the BIT External Degree Centre and the e-Learning Centre of UCSC for providing us support and necessary information to do this study.

\section{REFERENCES}

[1] G. Woodill, "Where is the Learning in E-learning? A Critical Analysis of the e-Learning Industry," 2004. [Online]. Available: http://www.e-learningguru.com/wpapers/e-Learning analysis.pdf. [Accessed: 12 May 2008].

[2] D. Bunis, "Commentary", College and University, vol.78, no.2. Fall 2003.

[3] D. R. Garrison and T. Anderson, E-learning in the 21st Century: A Framework for Research and Practice, Routledge, UK, 2003, pp. 14.

[4] L. Sherry, "Issues in distance learning," International Journal of Educational Telecommunications, vol. 1, no. 4, pp. 337-365, 1996.

[5] J. Gentilucci, "Constructivism and internet-based teaching at the International School of Information Management University," $E D$ Journal, vol. 8, p. 22-28, 1997.

[6] T. Boehler, "A design plan for online distance learning program delivery," [Unpublished] Ph.D. dissertation, Pepperdine University, Malibu, California, 1999.

[7] Y. Levy, "Comparing dropouts and persistence in e-learning courses," Computers and Education, vol. 48, no. 2, pp.185-204, 2007. (doi:10.1016/j.compedu.2004.12.004)
[8] S. B. Ecom, H. J. Wen and N. Ashill, "The determinants of students' perceived learning outcomes and satisfaction in university online education: An empirical investigation," Decision Sciences Journal of Innovative Education, vol. 4, no. 2, pp. 215235, 2006. (doi:10.1111/j.1540-4609.2006.00114.x)

[9] K. Swan, P. Shea, E. E. Fredericksen, A. M. Pickett and E. William, "Course design factors influencing the success of online learning," in Proceedings of WebNet 2000 - World Conference on the WWW and Internet, 2000, pp. 513-518.

[10] D. Lupo, and Z. Erlich, "Computer literacy and applications via distance e-learning," Computers and Education, vol. 36, pp. 333345, 2001. (doi:10.1016/S0360-1315(01)00022-7)

[11] R. P. Bostrom, L. Olfman and M. K. Sein, "The Importance of learning style in end-user training," MIS Quarterly, vol. 14 no.1, p101-119, March 1990. (doi:10.2307/249313)

[12] S. Kim and D.H. Sonnenwald, "Investigating the relationship between learning style preferences and teaching collaboration skills and technology: An exploratory study," in Proceedings of the ASIS\&T Conference, 2002, pp. 64-73.

[13] A. Valenta, D. Therriault, M. Dieter and R. Mrtek, "Identifying student attitudes and learning styles in distance education," Journal of asynchronous learning networks, vol. 5, no. 2, Sep. 2001.

[14] Gururajan, R., "End user computing: Learning style differences as a predictor of training outcomes", in Proceedings of the 10th Annual Teaching Learning Forum, 2001. [Online]. Available:http://lsn.curtin.edu.au/tlf/tlf2001/gururajan.html. [Accessed Aug. 2, 2008]

[15] G. Shaw, and N. Marlow, "The role of the student learning styles, gender, attitudes and perception on information and communication technology assisted learning," Computers and Education, vol. 33, pp. 223-234, 1999. (doi:10.1016/S03601315(99)00020-2)

[16] K. Downing and T. M. Chim, "Reflectors as online extraverts?" Educational Studies, vol. 30, no.3, pp. 265-276, 2004. (doi:10.1080/0305569042000224215)

[17] S. S. Liaw, H. Huang and G. Chen, "Surveying instructor and learner attitudes toward e-learning," Computers and Education, vol. 49, no. 4, pp. 1066-1080, 2006. (doi:10.1016/j.comp edu.2006.01.001)

[18] K. Sabry, and L. Baldwin, "Web-based learning interaction and learning styles," British Journal of Educational Technology, vol. 34, no. 4, pp. 443-454, 2003. (doi:10.1111/1467-8535.00341)

[19] K. D. Gunawardana, "An empirical study of potential challenges and benefits of implementing e-learning in Sri Lanka," in Proceedings of the Second International Conference on eLearning for Knowledge-Based Society, 2005. [Online]. Available: http://www.elearning.au.edu/research/elearning_conference_2005/ Proceeding2005\%20and\%20Book/PP33.pdf. [Âccessed: 5 May 2008]

[20] T.A. Weerasinghe, K.M.G.B. Nishakumari and K.P. Hewagamage, "Gap between theory and practice: Human factors in designing and developing effective e-Learning materials for a structured syllabus," in Proceedings of the Fourth International Conference on eLearning for Knowledge-Based Society, 2007. [Online], Available: http://www.ijcim.th.org/v15nSP3/P19eLearningAP_GepBetweenT heory.pdf. [Accessed: 5 May 2008]

[21] D. H. Stolovitch and E. J. Keeps, Telling Ain't Training, USA: ASTD, Publications Department, 2002, pp. 29-42.

[22] C. M. Reigeluth, Instructional-Design Theories and Models: An overview of their current status. Lawrence Erlbaum Associates, 1983, pp. 12.

[23] N. Chen and K. Lin, "Factors affecting e-learning for achievement," in Proceedings of the IEEE International Conference on Advanced Learning Technologies, 2002. [Online]. Available: $\quad$ http://ttf.ieee.org/icalt2002/proceedings/ t502 icalt148_End.pdf. [Accessed: 2 May 2008].

[24] M. Peacock, "Match or mismatch? Learning styles and teaching styles in EFL," International Journal of Applied Linguistics, vol. 11 , no. 1 , pp. 1-20, June 2001. (doi:10.1111/1473-4192. $\underline{00001)}$ 


\section{LEARNERS' SATISFACTION, LEARNING STYLE PREFERENCES AND EFFECTIVE USE OF AN OLE}

[25] L. L. Peng, "Applying learning style in instructional strategies," CDTL Brief, vol. 5, no. 7, pp.1-3, October 2002.

[26] A. Chapman, "Kolb learning style: Honey and Mumford's variation on the kolb system", businessballs.com, August 2003. [Online]. Available: http://www.businessballs.com/kolblea' rningstyles.htm. [Accessed: 2 September 2008].

[27] C. W. Allinson and J. Hayes, "The learning styles questionnaire: An alternative to Kolb's inventory?," Journal of Management Studies, vol. 25, no. 3, pp. 269-281, May 1988. (doi:10.1111/j.1467-6486.1988.tb00036.x)

[28] L. Owens and J. Barnes, Learning Preference Scales: Handbook and test master set, Australian Council for Education Research Ltd, Melbourne, 1992

[29] Y. H. Fung, A. S. P. Ho, and K. P. Kwan, "Reliability and validity of the learning styles questionnaire," British Journal of Educational Technology, vol. 24, no.1, pp.12-21, 1993. (doi:10.1111/j.1467-8535.1993.tb00637.x)

[30] P. Honey, Learning Style Questionnaire: 40-item version, Peter Honey Publications Ltd, pp. 49, 2008.

[31] G. Gamage, "Comparison of results: 2005 - 2006 year 1 results," [Unpublished] University of Colombo School of Computing, Sri Lanka, 2007.

[32] G. E. Hein, "Constructivist learning theory," CECA (International Committee of Museum Educators) Conference, Jerusalem, Israel, 1991. [Online]. Available: http://www.exploratorium.edu/ifi/resources/constructivistlearning. html. [Accessed 13 May, 2008].

[33] T. Greening, "Scaffolding for success in PBL," Med Educ Online, 1998 [Online]. Available: http://www.med-edonline.org/f0000012.htm. [Accessed: 21 August 2008]

[34] Beyth-Marom, R., Chajut, E., Roccas, S. and Sagiv, L., "Internetassisted versus traditional distance learning environments: factors affecting students' preferences," Computers \& Education, vol. 41, no.1, pp. 65-76, August 2003. (doi:10.1016/S03601315(03)00026-5)

[35] R. Turner-Bisset, "E-learning and the problem of history teacher education: Thoughts from a partial luddite," Journal for the Enhancement of Learning and Teaching, vol. 1, no. 1, pp.32, 2004

[36] G. Piccoli, R. Ahmad and B. Ives, "Web-based virtual learning environments: A research framework and a preliminary assessment of effectiveness in basic it skills training," MIS Quarterly, vol. 25, no. 4, pp. 401-426, 2001. (doi:10.2307/3250989)
[37] L. Motiwalla and S. Tello, "Distance learning on the internet: A Exploratory Study," The Internet and Higher Education, vol. 2, no. 4, pp. 253-264, 2000. (doi:10.1016/S1096-7516(00)00026-9)

[38] C. S. Cavanaugh, "The effectiveness of interactive distance education technologies in K-12 learning: A Meta-Analysis," ERIC document, $1999 . \quad$ [Online]. Available: http://eric.ed.gov/ERICDocs/data/ericdocs2sql/content_storage_01 /0000019b/80/17/92/bd.pdf. [Accessed: 2 May 2008]

[39] J. Lu, C. Yu, and C. Liu, "Learning style, learning patterns and learning performance in a WebCT-based MIS course," Information and Management, vol. 40, pp. 497-507, 2002. (doi:10.1016/S0378-7206(02)00064-2)

[40] G. Salmon, "Psychological and group learning perspectives: their relevance to e-learning," Presented at E-learning, London, February 2001. [Online]. Available: http://www.atimod.com/ research/presentations/PsyGroup.doc, [Accessed: 10 May, 2008].

[41] W. T. Dickens, "Cognitive ability," Forthcoming in The New Palgrave Dictionary of Economics, S. Durlauf, Ed. The Brookings Institution, 2007. [Online]. Available: http://www.brookings.edu/ /media/Files/rc/papers/2007/05educati on_dickens/05education_dickens.pdf. [Accessed: May 5, 2008].

\section{AUTHORS}

T. A. Weerasinghe is with the Computer and System Sciences Department, Stockholm University/KTH, 16440 Kista, Sweden (e-mail: Thushani@dsv.su.se).

R. Ramberg is with the Computer and System Sciences Department, Stockholm University/KTH, 16440 Kista, Sweden (e-mail: robban@dsv.su.se).

K. P. Hewagamage is with the University of Colombo School of Computing, 35 Reid Avenue, Colombo 7, Sri Lanka (e-mail:kph@ucsc.cmb.ac.lk).

This work is supported by a SIDA (Swedish International Development Cooperation Agency) granted project at the University of Colombo School of Computing, Sri Lanka.

This is an extended version of the paper, "An Empirical Study: A Success Story of Effectiveness of an OLE" presented at ICL2008 conference in Villach, Austria, September 2008. Manuscript received 05 December 2008. Published as submitted by the author(s). 